\title{
利根川上流域における降雨パターンに着目した 洪水流出解析とダムの治水効果の評価 \\ RAINFALL-RUNOFF ANALYSIS FOCUSED ON RAINFALL PATTERN AND ASSESSEMENT OF DAM EFFECTS ON FLOOD CONTROL IN TONE UPPER RIVER BASIN
}

\author{
吉見和紘 1 - 山田正 ${ }^{2}$ \\ Kazuhiro YOSHIMI and Tadashi YAMADA \\ 1学生会員 中央大学大学院 理工学研究科土木工学専攻（†112-8551 東京都文京区春日1-13-27） \\ 2フェロー会員 工博 中央大学教授 理工学部都市環境学科（†112-8551 東京都文京区春日1-13-27）
}

\begin{abstract}
To clarify the effects of difference from rainfall pattern on runoff phenomenon contributes to the further development of the flood control measures commencing with dam control. Elucidating those effects is very useful to examine flood control plan. In this study, authors made pseudo rainfall patterns based on Typhoon Kathleen in September 1947 in Tone upper river basin and examined the effects of difference from rainfall pattern we created on runoff phenomenon. Moreover, authors verified the flood-control ability of Yanba dam in Agatsuma basin. In consequence, it was indicated that peak discharge at Yattajima point of observation was up 15 percentage point from peak discharge in Typhoon Kathleen depending on rainfall pattern. Furthermore, it was indicated that Yanba dam is 4 percent effective in decreasing water level at Yattajima point.
\end{abstract}

Key Words: difference from rainfall pattern, Tone upper river basin, runoff, peak discharge, dam effects on flood control

\section{1. はじめに}

気候変動に伴い降雨形態の変化が予測される中，降雨 パターンの違いが流出現象に与える影響を解明する事は, 従来から行われてきた多様な治水手法の組み合わせによ る総合的な治水対策の更なる発展に寄与し，治水計画を 検証する上で非常に有益である.

我が国はアジアモンスーン地域に位置し，梅雨期や台 風期に数時間程度の短時間に集中した大雨が降るという 降雨特性を有している. また, かつての洪水常襲地域に おける宅地開発，流域の土地利用形態の変化，平坦地が 少なく全国土の $10 \%$ に過ぎない洪水氾濫域に高密度な社 会経済活動が展開されている点など, 治水上非常に厳し い環境にある。そこで，我が国では堤防嵩上げや河床掘 削，引堤，放水路，遊水地，ダムなどによる多様な治水 手法の組み合わせによる治水対策が施されてきた.

また近年，地球温暖化による降雨形態の変化などの問
題が指摘され，様々な機関から近年の異常気象や長期的 な気候変動に関して報告書が発行されている. 例えば, IPCC 第4次報告書 ${ }^{1)}$ に示されるように, 地球温暖化によ る降雨形態の変化が予測されている. IPCC第4次報告 書では, 20 世紀後半, 北半球中・高緯度域においては, 大雨の発現頻度が2〜 4\%増加した可能性が高いと述べら れるとともに，自然現象の極端化，例えば，将来の温暖 化した気候において，夏季はより乾燥し渴水の危険性が 高まり，冬季はより湿潤となり強い降水や洪水の危険性 が増大すると指摘されている. 実際, 日本においても, 平成23年7月の新潟・福島豪雨, 同年台風12号による被 害，平成24年7月の九州北部豪雨など，記録的な豪雨に より河川が汇濫もしくは決壊するような甚大な被害が発 生している.

以上より, 降雨パターンの違いや降雨強度の増大によ る流出現象一の影響を明らかにする事は，我が国におけ る総合的な治水対策の確立のためにも重要であると考え る. 本論文では, 利根川上流域を対象として, 降雨パ 
ターンの違い及び降雨強度の増大がピーク流量に与える 影響について検証した．また，治水対策において重要な 役割を果たすダム群の操作手法の確立を将来的な目的と し，利根川上流の吾妻川流域を対象に，八ッ場ダムの有 無によるピーク流出量の違いについて検証した.

\section{2. 単一斜面における降雨流出の基礎式の概要}

山田ら 2) $^{2}$, 従来から単一斜面における一般化した降 雨流出の基礎式を提案している. 以下にその理論の概要 を記す．単一斜面に対して幅広矩形断面を想定するとと もに，様々な流出形態に対応するため運動則を式(1)に示 すよう，断面平均流速は水深のべき乗に比例するという 形式で表現する，一般的なKinematic Wave理論における 式(1)の表現は, 著者らの記述方法とは異なり, 単位幅流 量 $q$ が水深のべき乗に比例する形式で記述する事が多い ので幕数 $m$ の值に注意されたい. 連続式に関しては式 (2)で表現される. (2)式と(1)式より単位幅流量 $q$ にいて の(3)式を得る.

$$
\begin{gathered}
v=\alpha h^{m}, \quad q=v h=\alpha h^{m+1} \\
\frac{\partial h}{\partial t}+\frac{\partial q}{\partial x}=r(t) \\
\frac{\partial q}{\partial t}+a q^{\beta} \frac{\partial q}{\partial x}=a q^{\beta} r(t) \\
a=(m+1) \alpha^{\beta} \quad(4), \quad \beta=\frac{m}{m+1}
\end{gathered}
$$

ここに, $v$ : 断面平均流速 $[\mathrm{mm} / \mathrm{h}], h:$ 湛水深 $[\mathrm{mm}]$, $q$ : 単位幅流量 $\left[\mathrm{mm}^{2} / \mathrm{h}\right], r(\mathrm{t}):$ 降雨強度 $[\mathrm{mm} / \mathrm{h}], \alpha, m$ は 流域特性を表すパラメータである。直接流出は流出寄与 域（河道及び河道近傍の湿潤領域）のみからの流出と考 えると，斜面長は実地形上の斜面長より十分短いものと 考えられ，(6)式に示寸変数分離形の近似式が仮定できる.

$$
q(x, t) \cong x q_{*}(t)
$$

ここに, $q_{*}$ : 流出高 $[\mathrm{mm} / \mathrm{h}]$ である. また, 斜面長 $L$ の 末端で考え $x=L$ として(6)式を用いると，偏微分方程式で ある(3)式は(7)式に示すように流出高に関する常微分方 程式に変形できる.

$$
\frac{d q_{*}}{d t}=a_{0} q_{*}^{\beta}\left(r(t)-q_{*}\right)
$$

ただし,$\quad a_{0}=a L^{\beta-1}=(m+1)\left(\frac{\alpha}{L}\right)^{\frac{1}{1+m}}$

ここに, $L$ : 流出寄与域斜面長である. (7)式が一般化 された単一斜面からの降雨流出の基礎式となる.

土壌・地形特性を示寸流出パラメータ $\alpha$ と $m$ の值に関 して志村ら (3) $^{3}$ 鈴木 ${ }^{4), 5)}$, 窪田らのの不飽和浸透理論と
Kinematic Wave法の式展開を比較する事により式(9),(10) で示されるよう，土壤・地形特性から決定できる事を示 している.

$$
\alpha=\frac{k_{s} i}{D^{\gamma-1} w^{\gamma}} \quad(9), \quad m=\gamma-1
$$

ここに, $i$ : 斜面勾配, $D:$ 表層土層厚 $[\mathrm{mm}], \gamma:$ 土壤 の透水性を表す無次元パラメータ, $k_{s}$ : 飽和透水係数 $[\mathrm{mm} / \mathrm{h}], w$ : 有効空隙率であり, $w=\theta_{s}-\theta_{r}\left(\theta_{s}\right.$ : 飽和含水率, $\theta_{r}$ : 残留含水率)で定義される. これにより, 斜面流下方 向流れに関して飽和・不飽和側方流を対象とする場合,

土畩・地形特性から流出パラメータを決定し降雨流出計 算を行う事が可能である。 また，尅らొは，式(11)に示す 表面流，鉛直浸透流，飽和・不飽和側方流に関する多層 流れを考慮した降雨流出計算手法を提案し, 土壤・地形 特性と降雨強度の関係から表面流の発生が表現可能であ る事を示している.

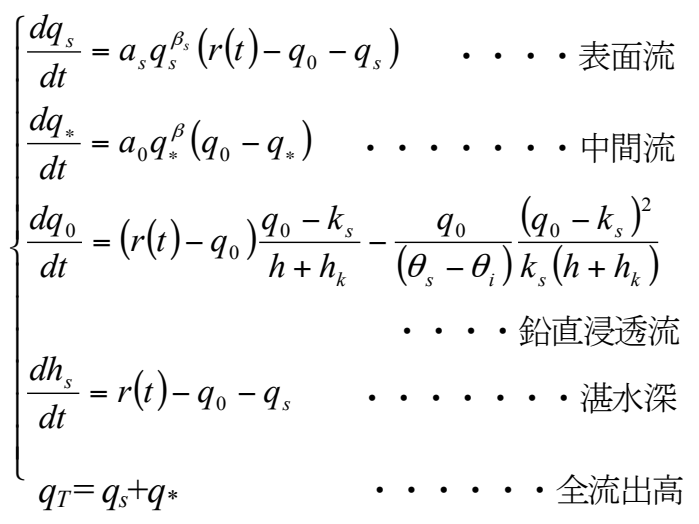

ここに, $q^{*}$ : 飽和・不飽和側方流に関する流出高 $[\mathrm{mm} / \mathrm{h}], q s$ : 表面流に関する流出高 $[\mathrm{mm} / \mathrm{h}], q_{T}$ :全流出高 $[\mathrm{mm} / \mathrm{h}], q 0$ : 鉛直浸透流 $[\mathrm{mm} / \mathrm{h}], h_{s}$ : 湛水深 $[\mathrm{mm}], h_{k}:$ 湿 潤線での毛管負圧 $[\mathrm{mm}]$ である. 表面流はManning則をと $\eta$, 抵抗則 $m_{s}=2 / 3, \alpha_{s}=i^{12} / n$ で表され，表面流に関する流出 パラメータ $a_{s}$ おび $\beta_{s}$ が求まる. ここで， $n$ は斜面表層に おけるManningの粗度係数である.

また, (11)式中の降雨強度 $r(t)$ は有効降雨強度であり, 本論文では, 山田らが提案している保水能の理論により 決定している．詳細は参考文献》を参照されたい.

\section{3. 対象流域と計算手法}

\section{（1）対象流域}

図-1に示寸通り，利根川上流域 $\left(5110 \mathrm{~km}^{2}\right)$ は，奥利根 流域 $\left(1670 \mathrm{~km}^{2}\right)$, 吾妻川流域 $\left(1680 \mathrm{~km}^{2}\right)$, 烏川流域 $\left(1320 \mathrm{~km}^{2}\right)$, 神流川流域 $\left(440 \mathrm{~km}^{2}\right)$ のつの中流域で構成さ れる.また，利根川上流域には複数のダムが存在する. 奥利根流域の矢木沢ダム，奈良俣ダム，藤原ダム，相俣 ダム, 薗原ダムの 5 ダムは首都圈の洪水対策及び水資源 確保に重要な役割を担っている.さらに，烏川流域の下 


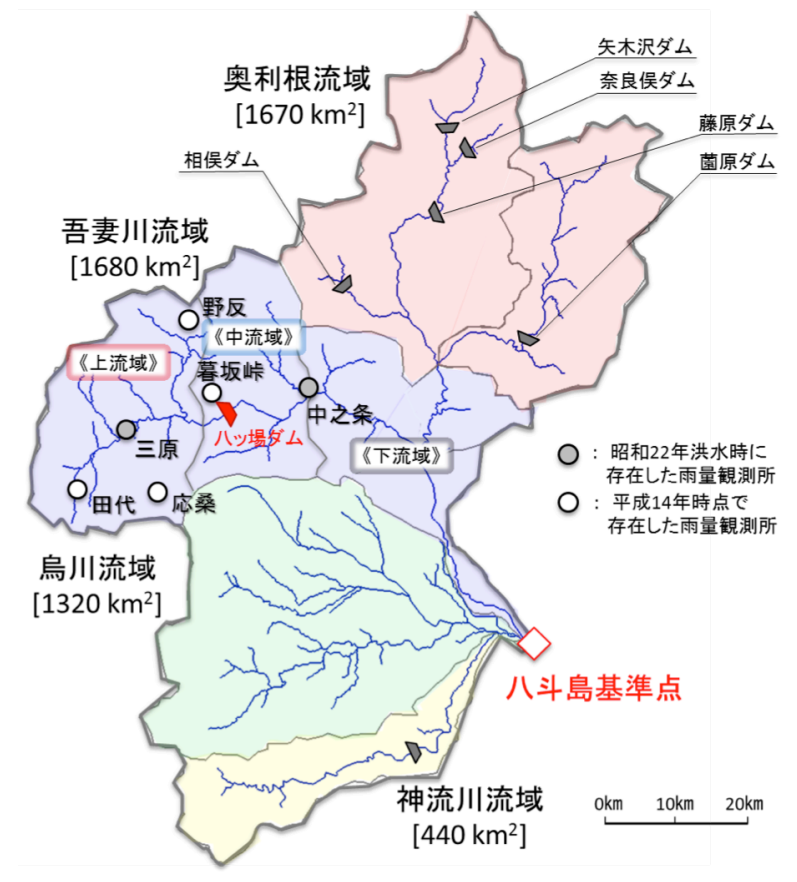

図-1 利根川上流域及び二次河道網, 主要7ダム及び吾妻川流 域雨量観測所位置図, 実測流量観測所地点 (八斗島基準 点:河口から181.45km).

久保ダム，現在建設中の八ッ場ダムを含めた利根川上流 域ダム群での合理的な洪水対策，利水政策を考える必要 がある，本論文の流出計算における懸案地点は，利根川 河口から $181.45 \mathrm{~km}$ 地点に位置する八斗島基準点である.

\section{（2）計算手法}

本論文は表面流，鉛直浸透流，飽和・不飽和側方流に 関する多層流れを考慮した降雨流出計算手法（式(11)） により斜面流出計算を行い，その出力を受けて河道計算 を行うことで一連の流出計算を行なっている．河道部の 計算は一次元不定流計算であり, 連続式(12)式と運動量 保存式(13)式を用いて計算している，水位計算点と流量 計算点を異なる格子点で定義し計算を行う6-point Abbott Scheme ${ }^{8)}$ によって解いている.

$$
\begin{gathered}
\frac{\partial A}{\partial t}+\frac{\partial Q}{\partial x}=q \\
\frac{\partial Q}{\partial t}+\frac{\partial\left(\alpha \frac{Q^{2}}{A}\right)}{\partial x}+g A \frac{\partial h}{\partial x}+\frac{n^{2} g Q|Q|}{A R^{4 / 3}}=0
\end{gathered}
$$

ここに, $A$ :通水断面積 $\left[\mathrm{m}^{2}\right], Q$ :流量 $\left[\mathrm{m}^{3} / \mathrm{s}\right], q$ :側方流 入単位幅流量 $\left[\mathrm{m}^{2} / \mathrm{s}\right], \quad \alpha(=1.0)$ : エネルギー補正係数, $g$ :重 力加速度 $\left[\mathrm{m} / \mathrm{s}^{2}\right], n:$ Manningの粗度係数, $R$ :径深 $[\mathrm{m}]$ である.

\section{（3）流出パラメータの空間分布}

既往の研究9 により, 利根川上流域程度の流域面積で あれば，水文特性の空間分布が降雨流出に与える影響は 小さく，流域平均值としての水文諸量を用いれば，流出
計算結果にほとんど差異が表れない事が示されている. 本論においては, 斜面長 $L=30[\mathrm{~m}]$, 表層土層厚 $D=20[\mathrm{~cm}]$, 有効空隙率 $w=0.42$, 斜面勾配 $i=15^{\circ}$, 抵抗則 $m=4$ を各中流 域に一様に与えた。 これらの水文諸量は, 利根川水系渡 良瀬川流域を対象とした流出計算時に同定した值”及び, 中央大学が所有する春日試験地で実際に観測された值を 参考に決定しており，現在考光得る最良のパラメータで あるとして流域一様に与えている.

また，河道計算では，河道位数の概念に基づいて全流 域面積を河道長の比で重み付けし，142のサブ流域（奥 利根流域:28分割, 吾妻川流域:54分割, 烏川流域:52分割, 神流川流域:8分割）に分割している.

\section{4. 吾妻川流域の降雨パターンの違いが八斗島地}

\section{点のピーク流量に与える影響}

治水計画を検討寸る上で，台風の経路は一様でない事 や温暖化による気象現象の極端化を考え, あらゆる降雨 パターンを想定した流出計算が重要となる。本節では, 利根川上流域の中でも従来から降雨量が少ないとされる 吾妻川流域を対象に降雨強度を変化させた流出計算を行 い, 八斗島基準点のピーク流量に与える影響に関して検 証した.

\section{（1）吾妻川流域の降雨分布}

吾妻川上流域は雨が降りにくい地域と言われており， 昭和22年9月洪水時の吾妻川上流域の総降雨量は他流域 と比較すると少ないとされている，しかしながら，昭和 22年9月洪水時に実存した雨量観測所は，三原雨量観測 所及び中之条雨量観測所であり, 現在と比較して雨量観 測所の数が極めて少なく，一つの雨量観測所が支配する 面積が大きい事などから, 当時の詳細な雨量分布を知る 事は不可能である.

そこで, 吾妻川上流域の降雨量分布を調べるため, 1951年から2011年までの降雨データを用いて, 単一降雨 イベントにおける標高と総降雨量の関係を検証した。

\section{a）点による比較（上流域と中・下流域で1点ずつ選定）}

中・下流域代表地点として図-1に示寸中之条雨量観測 所（標高 : $351 \mathrm{~m}$ ），上流域代表地点として田代雨量観 測所（標高：1230m）を選定し，両雨量観測所における 60年間の降雨量データから, 標高と総降雨量の関係を検 証した．本論文における吾妻川上流域，中流域，下流域 の区分は図-1に示すとおりである.

検証結果を図-2に示す．図-2より，上流域の地点にお いて平野部の地点よりも最大で2倍近い降雨が発生して いる降雨イベントがある事がわかった. 
b）空間的な比較（地上雨量計とレーダ解析雨量を使用 した比較)

a)の結果に加えて，図-2から局地的な降雨イベントが 存在することがわかる，そこで，地上雨量計を用いた空 間的な比較及びレーダ解析雨量を用いて上流域と中流域 で同様の比較を行った．結果を図-3に示す．図-3に示す 青い点は, 中之条雨量観測所（標高：351m）の総降雨 量と八ッ場ダム建設地点に最も近い暮坂趾雨量観測所 （標高：1110m）及びダムサイトより上流域に位置する 野坂雨量観測所（標高：1490m），応桑雨量観測所（標 高 : 1100m），田代雨量観測所（標高：1230m）のそれ ぞれの総降雨量を比較したものである（観測期間： 1998-2008）。赤い点は，吾妻川中流域と上流域のレー ダ解析雨量から得た総降雨量である（観測期間：19952008）。どちらの比較においても，単一降雨イベントに おいて1.5倍〜2.0倍近い降雨量もしくはそれ以上の降雨 量が上流域で降っているケースがある事がわかった。

吾妻川上流域は，従来から雨が降りにくい地域とされ ていたが，上述の通り，中・下流域で小降雨の際に上流 域で豪雨が発生している降雨イベントがある事がわかっ た.

\section{（2）吾妻川流域の降雨パターンの違いが八斗島地点の ピーク流量に与える影響}

4. (1)の結果を踏まえ, 昭和 22 年9月洪水時の中之条 雨量観測所（標高： $351 \mathrm{~m}$ ）で得られた降雨データを用 いて，降雨強度を引き伸ばした降雨を現在田代雨量観測 所が存在する地点（標高：1230m）に与えて流出計算を 行い, 八斗島地点の流出量に関して, 田代雨量観測所地 点に降雨を与えない場合と比較した。 ここで，田代雨量 観測所に降雨を与えない場合とは，昭和22年9月洪水時 の再現計算の事であり，利根川上流域の基本高水流量は, この昭和 22 年 9 月洪水を基に $22000 \mathrm{~m}^{2} / \mathrm{s}$ と定められている. 本節の結果である図-4に詳細を示寸が，再現計算で得ら

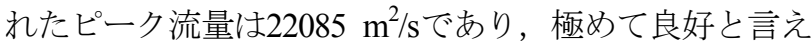
る（以下，この再現計算を昭和 22 年 9 月洪水計算と呼 ぶ) .

田代雨量観測所に与えた降雨は，中之条雨量観測所で 得られた時間降雨データを各時間で1.5倍及び2倍に引き 伸ばした降雨である，両ケースの降雨ともに，三原雨量 観測で観測された降雨データ，中之条雨量観測所で観測 された降雨データ及び田代雨量観測所に与えた降雨デー 夕を用いて，ティーセン法によって流域平均降雨量を算 出している.これらと，中之条雨量観測所と三原雨量観 測所の降雨データを用いてティーセン法によって流域平 均降雨量を算出し流出計算したものと比較している。

流出計算を行った結果を図-4に示す，昭和22年9月洪 水計算と中之条雨量観測所で得られた降雨を1.5倍に引

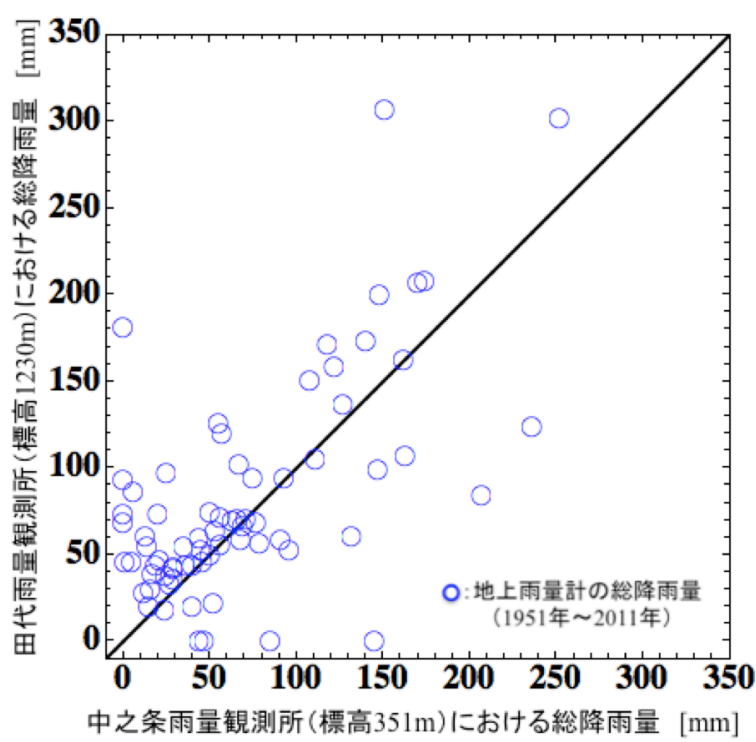

図-2 中之条雨量観測所（351m） と田代雨量観測所 (1230m) の降雨イベント毎の総降雨量の関係, 地上 雨量計のデータを使用（観測期間:1951-2011）

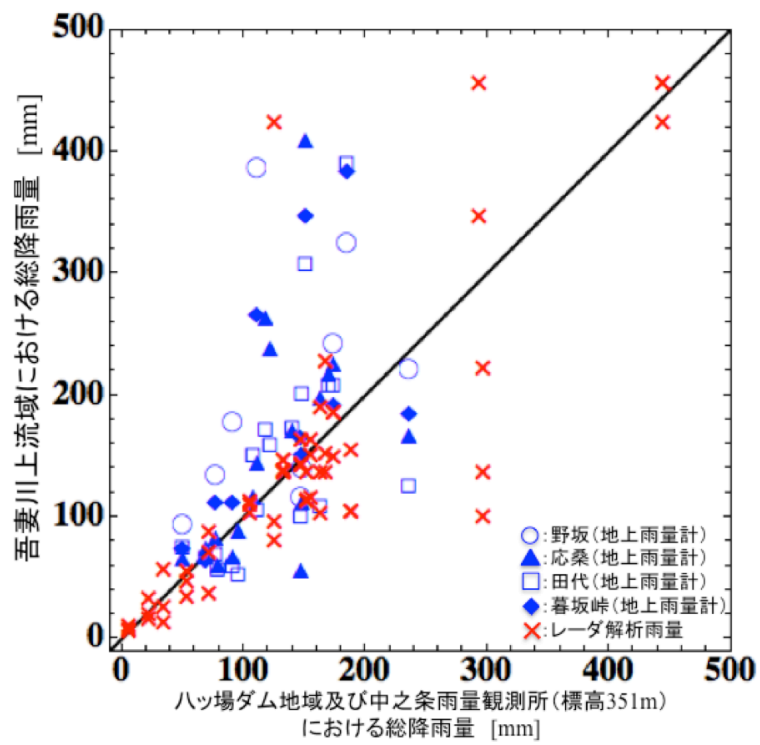

図-3 吾妻川上流域と中流域の降雨イベント毎の総降雨量の 関係, 地上雨量計及びレーダ解析雨量のデータを使用 （観測期間 : 1995-2008）

き伸ばした降雨を田代雨量観測所に与えた計算結果（以 下，類推1.5倍降雨計算と呼ぶ）を比較した場合，八斗 島基準点におけるピーク流量の差は約 $1100 \mathrm{~m}^{3} / \mathrm{s}$ となる事 を示した。同様に昭和22年9月洪水計算と中之条雨量観 測所で得られた降雨量の2倍の降雨を田代雨量観測所に 与えた場合の計算結果（以下，類推 2 倍降雨計算と呼ぶ) を比較した場合，八斗島基準点におけるピーク流量の差 は約 $3200 \mathrm{~m}^{3} / \mathrm{s}$ となる事を示した。

以上の結果から，昭和22年9月洪水時に吾妻川上流域 により多くの雨が降った場合，即ち，吾妻川流域の流域 平均降雨量が100〜200mm増加したと仮定した場合，八 斗島基準点でのピーク流量が類推 1.5 倍降雨計算の結果 約 $23000 \mathrm{~m}^{3} / \mathrm{s}$ となり, 類推 2 倍降雨計算の結果約 $25000 \mathrm{~m}^{3} / \mathrm{s}$ 


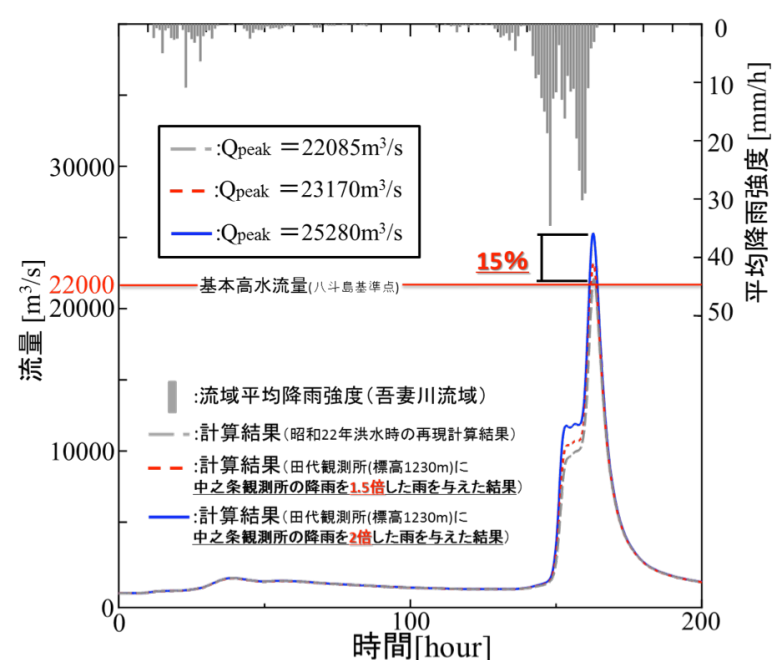

図-4 吾妻川上流域の降雨量が増加した際の八斗島基 準点における洪水ハイドログラフ.

となる事を示した．表-1に示寸通り，八斗島上流域の4 つの中流域の内，吾妻川流域の流域平均降雨量の増加率 が約 $6 \%$ に対して，八斗島基準点のピーク流量の増加率 が約15\%である事は非常に興味深い.

流域平均降雨量の増加率に対してピーク流量の増加率 が大きいのは，昭和 22 年 9 月洪水時の降雨ハイエトグラ フが短時間集中型である事が理由の1つであると考えら れる.また，図-4に示寸通り，先行降雨の影響により， 土壤が飽和に近い状態で主要降雨イベントが発生したか らであると考えられる.

\section{5. 利根川上流域の降雨パターンの違いが八斗島}

地点のピーク流量に与える影響

藤原 ${ }^{10)}$, Kim et al. ${ }^{11}$ は, 利根川流域の年降水量は今 後増加する可能性がある事を示している．地球温暖化に 伴う降水現象の極端化，特に降雨量・強度の増加が指摘 される中，あらゆる降雨パターンを想定した流出計算を 行う事は治水計画を考える上で重要である.

前節では，利根川上流域のうち，吾妻川流域のみの降 雨量が変化した場合に八斗島基準点のピーク流量にどの ような影響が表れるかを検証した，本節では，利根川上 流域における降雨パターンの違いが流出計算結果に与え る影響を検証した。昭和 22 年9月洪水時の降雨イベント

表-1 吾妻川上流域の降雨量変化による流域平均降雨 量とピーク流量の増加割合.

\begin{tabular}{|c|c|c|}
\hline & $\begin{array}{c}\text { 吾妻川上流域の } \\
\text { 流域平均降雨量の増加割合 }\end{array}$ & $\begin{array}{c}\text { 八斗島基準点の } \\
\text { ピ流量の増加割合 }\end{array}$ \\
\hline 昭和22年9月洪水計算 & $1.00(352[\mathrm{~mm}])$ & $1.00\left(22085\left[\mathrm{~m}^{3} / \mathrm{s}\right]\right)$ \\
\hline 類推1.5倍降雨計算 & 1.03 & 1.12 \\
\hline 類推2.0倍降雨計算 & 1.06 & 1.15 \\
\hline
\end{tabular}

を基に，利根川上流域内の4つの中流域の各ハイエトグ ラフを入れ替え，降雨パターンを作成した，一般的に各 降雨イベントは独立な事象であり，相関はないと考えら れる，それらを入力降雨と寸る事で，相関なく独立で， かつ昭和 22 年9月洪水時と同等の降雨イベントにおける 降雨パターンの違いと流出量の関係について検証するこ とが可能である.

以下に示寸降雨パターンは，4つの中流域のうち，上 流側の 2 流域（奥利根，吾妻川流域）に400mm以上の雨 が降った場合の擬似降雨である.下流側の 2 流域で多く の降雨量が降ったとされている昭和 22 年9月洪水時とは 雨の降り方が大きく異なる場合である.

パターン 1 : 奥利根流域と烏川流域の降雨量を入れ替え, 吾妻川流域と神流川流域の降雨量を入れ替 えた計算

パターン2 : 吾妻川流域と烏川流域の降雨量を入れ替え, 奥利根流域と神流川流域の降雨量を入れ替 えた計算

表-2に示寸通り，昭和22年9月洪水時の流域平均降雨 量を基準とした利根川上流域の流域平均降雨量の増加率 はそれぞれ $11 \%$ と $20 \%$ であり，ピーク流量の増加率はそ れぞれ $10 \%$ と $17 \%$ であった。昭和 22 年9月洪水時，奥利 根流域及び吾妻川流域の流域平均降雨量は少なかったが, この2流域に大量の雨が降るような降雨パターンの場合， 昭和22年9月洪水時を上回る規模の出水が生じていた可 能性を示唆する。

\section{6. ダムの持つ治水機能}

4. (2)の結果を踏まえ，S22年9月洪水当時に，吾妻川 流域に八ッ場ダムが存在したと仮定した場合の流出解析 の結果を示す，本節では，吾妻川流域に八ッ場ダムが存 在した場合，ダムの持つ洪水調節機能がどの程度である かを定量的に評価する事を目的とする。

ダム操作手法は現在予定されている放流方式を参考に, 一定量放流方式を採用した．本計算では，カット開始流 入量を $700 \mathrm{~m}^{3} / \mathrm{s} \sim 1500 \mathrm{~m}^{3} / \mathrm{s}$ まで $200 \mathrm{~m}^{3} / \mathrm{s}$ 刻みで変化させる 事 (全5ケース) により，ダムの持つ治水容量を最大限 に活用できる貯留量を調べた。また，ダム制御がない場 合とある場合に八斗島基準点における洪水制御効果を検

表-2 利根川上流域の降雨パターンの違いによる流域 平均降雨量とピーク流量の増加割合.

\begin{tabular}{|c|c|c|}
\hline & $\begin{array}{c}\text { 利根川上流域の } \\
\text { 流域平均降雨量の増加割合 }\end{array}$ & $\begin{array}{c}\text { 八斗島基準点の } \\
\text { ピ流量の増加割合 }\end{array}$ \\
\hline 基準 & $1.00(380[\mathrm{~mm}])$ & $1.00\left(22085\left[\mathrm{~m}^{3} / \mathrm{s}\right]\right)$ \\
\hline パターン1 & 1.11 & 1.10 \\
\hline パターン2 & 1.20 & 1.17 \\
\hline
\end{tabular}




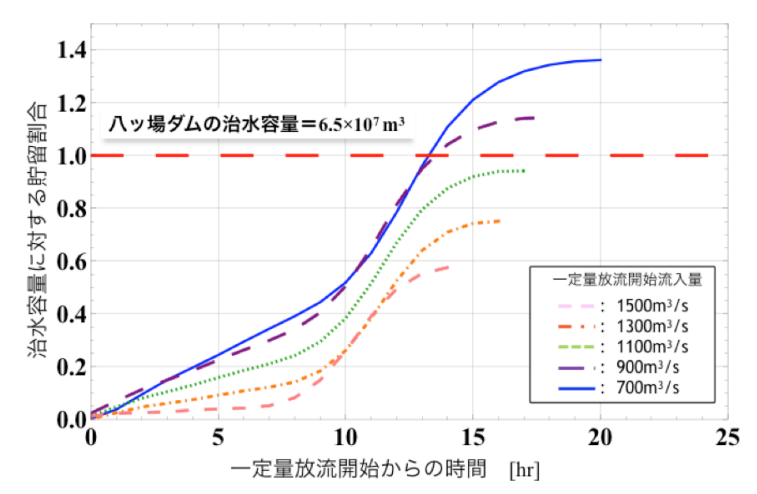

図-5 八ッ場ダムにおける一定量放流開始からの時間と治 水容量に対する貯留割合の時間変化.

証した。

図-5に示寸通り，S22年 9 月洪水時に流入量 $1500 \mathrm{~m}^{3} / \mathrm{s}$ か ら一定量放流方式でダム制御を行った場合，治水容量の 6割程度まで貯留する事が可能である。また，同洪水時 に流入量 $700 \mathrm{~m}^{3} / \mathrm{s}$ 及び $900 \mathrm{~m}^{3} / \mathrm{s}$ から一定量放流を開始する 之，両者とも一定量放流開始から約 13 時間後に，八ッ場 ダムの治水容量 $6.5 \times 10^{7} \mathrm{~m}^{3}$ を上回る事がわかる. よって, 流入量 $1100 \mathrm{~m}^{3} / \mathrm{s}$ から放流を開始した場合に治水容量に対 して9割以上貯留する事が可能であり，八ッ場ダムの持 つ治水能力を最大限に活かせる事がわかった.

各地点におけるダム制御がない場合とある場合の水深 比は図-6に示す通りであり，八斗島基準点ではダム制御 がない場合と比較して最大 $4 \%$ ，水深にして $0.4 \mathrm{~m}$ 近い低 減効果が見込める事を示した.

\section{7. まとめ}

吾妻川流域の降雨量の増加及び利根川上流域の降雨パ ターンの違いが八斗島基準点のピーク流量に与える影響 について検証した。 また，S22年9月洪水時を対象として, 吾妻川流域に現在建設中の八ッ場ダムの有する治水効果 を評価した結果, 以下の結論を得た。

1) 吾妻川流域の流域平均降雨量が3〜 6\%増加させた流 出計算を行った場合，集水域を利根川上流域とする 八斗島基準点において，ピーク流量が $12 \sim 15 \%$ の上昇 する.

2) 利根川上流域に異なる降雨パターンを与えた流出計 算の結果，下流域に比べ上流域の降雨量が多い場合 では，S22年9月洪水時の再現計算と比較すると， ピーク流量に10〜17\%の上昇が見られる.

3) 吾妻川流域に現在建設中の八ッ場ダムは，S22年9月 洪水時に $1100 \mathrm{~m}^{3} / \mathrm{s}$ から一定量放流を開始寸る事で, 治水容量を最大限に活用できる.

4) S22年9月洪水を対象として，八ッ場ダムの治水効果を 検証した結果，八斗島基準点において，最大で4\%の水 位低減効果がある事がわかった.

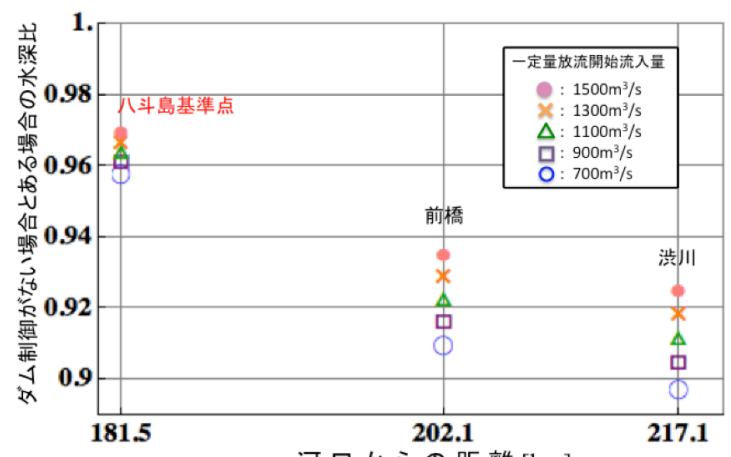

河ロからの距離 $[\mathrm{km}]$

図-6 ダム制御を行わない場合と一定量放流を行った場合 の八斗島基準点における水深比.

謝辞 : 本研究は科研費挑戦的萌芽研究（代表者 山田正） からの支援を受けて実施されている。ここに記して謝意 を表します。

\section{参考文献}

1) IPCC,2007: CLIMATE CHANGE 2007 -The Physical Science Basis-,IPCC FOURTH ASSESSMENT REPORT, Technical Summary, pp.19-92, 2007.

2) 山田正:山地流出の非線形性に関する研究, 土木学会水工学 論文集, Vol.47,pp.259-264,2003.

3）志村光一，大原憲明，松本浩志，山田正:水理計算に基づく 大規模河道網の洪水流出特性に関する研究，水文・水資源 学会誌, Vol.14,No.3,pp.217-228,2001.

4) 鈴木雅一: 山地流域の基底流出逈減特性( I ), 日林誌, Vol.66,pp.174-182,1984.

5) 鈴木雅一:山地流域の基底流出莪減特性( II ), 日林誌, Vol.66,pp.211-218,1984.

6) 窪田順平，福嶌義宏，鈴木雅一:山腹斜面における土壌水分 変動の観測とモデル化(II)一水収支および地下水発生域の 検討一，日林誌，Vol.70,No.9,pp.381-389,1988.

7）吳修一，山田正，吉川秀夫:表面流の発生機構を考慮した斜 面多層降雨流出計算手法に関する研究，水文・水資源学会 誌, Vol.49,pp.169-174,2005.

8) Abbott M B, Ionescu F: On the numerical computation of nearlyhorizontal flows, Journal of Hydraulic Research, 5(2), 97-117, 1976.

9) K Oda, S Kure, T Yamada, R Ebana, A Watanabe, N Watanabe: Effects of Special Distribution of Hydrological Characteristics to Runoff, World City Water Forum, CD-ROM, 2009.

10) 藤原洋一, 大出真理子, 小尻利治, 友杉邦雄, 入江洋樹:地 球温暖化が利根川上流域の水資源に及ぼす影響評価，水工 学論文集，第50巻，pp.367-372，2006年2月.

11) S Kim, Y Tachikawa, K Takara, E Nakakita: Hydrologic Prediction under Global Warming at Tone and Yodo River Basins using the Output of Global 20-km Mesh GCM, Annuals of Disas. Prev. Res. Inst., Kyoto Univ., No.51 B, 2008.

(2012. 9. 30受付) 